\title{
MODIFIKASI SCREEN PRINTED CARBON ELECTRODE DENGAN POLIMER TERCETAK MOLEKUL (MIP) DAN APLIKASINYA UNTUK DETEKSI GLUTATION
}

\author{
Eti Rohaeti, Wulan Tri Wahyuni*, Moh Arif Rohman Nur Hakim \\ Divisi Kimia Analitik Departemen Kimia Fakultas MIPA Institut Pertanian Bogor \\ Gedung Departemen Kimia Wing 2 Level 1, Jalan Tanjung No.3 Kampus IPB Dramaga, Bogor
}

\author{
wulantriws@apps.ipb.ac.id
}

Artikel Info
Diterima
tanggal
20.01 .2018
Disetujui
publikasi
tanggal
30.04.2018

Kata kunci :
Glutation, MIP,
polipirola,
SPCE,
SPCE. \begin{abstract}
glutation. Kinerja SPCE-MIPpy dalam pengukuran GSH disimpulkan lebih optimum dibandingkan
ABSTRAK

Penelitian ini bertujuan memodifikasi screen printed carbon electrode (SPCE) dengan polimer tercetak molekul (MIP) dan mengaplikasikannya untuk deteksi glutation tereduksi (GSH) secara tidak langsung dengan mediator bromin menggunakan teknik voltammetri siklik. SPCE dimodifikasi dengan MIP polipirola (MIPpy) melalui teknik elektrodeposisi. Pengukuran GSH dilakukan dalam elektrolit $\mathrm{NaClO}_{4}$ 0.2 $\mathrm{M}$ yang mengandung $1 \mathrm{mM} \mathrm{NaBr}$. Hasil yang diperoleh menunjukkan SPCE-MIPpy telah berhasil diperoleh melalui teknik elektrodeposisi. Pada pengukuran diperoleh puncak oksidasi bromida pada potensial $\pm 0.63 \mathrm{~V}$ vs. $\mathrm{Ag} / \mathrm{AgCl}$. Puncak ini berkorelasi linear dengan konsentrasi GSH dalam larutan sehingga dapat digunakan sebagai dasar penentuan GSH. Polipirola meningkatkan konduktivitas listrik elektrode sehingga dapat meningkatkan puncak arus oksidasi GSH. Pengukuran glutation dengan SPCE-MIPpy menunjukkan limit deteksi dan limit kuantitasi yang lebih baik dibandingkan SPCE, yaitu sebesar $7.6626 \mu \mathrm{M}$ dan $25.4092 \mu \mathrm{M}$. Keberadaan interference glukosa tidak mengganggu pengukuran
\end{abstract}

\section{ABSTRACT}

This study aims to modify screen printed carbon electrode (SPCE) using molecularly imprinted polymer (MIP) and applied this electrode for indirect detection of glutathione (GSH) in the present of bromine as mediator using cyclic voltammetry. MIP modified SPCE was obtained by using electrodeposition of pyrrole on SPCE surface. GSH measurement was conducted in $\mathrm{NaClO}_{4} 0.2 \mathrm{M}$ with 1 $\mathrm{mM} \mathrm{NaBr}$. The result indicated that molecularly imprinted polymer polypyrrole (MIPpy) modified SPCE was successfully made bu using electrodeposition method. Measurement of GSH in $\mathrm{NaClO}_{4} 0.2 \mathrm{M}$ with addition of $\mathrm{NaBr} 1 \mathrm{mM}$ at SPCE and MIPpy modified SPCE (SPCE-MIPpy) provided oxidation peak of bromide at potential of $\pm 0.63 \mathrm{~V}$ vs Ag/AgCl. This peak is linearly correlated to the concentration of GSH in the solution and could be used for measurments of glutathione. Polypyrrole increase electrical conductivity of the electrode, thus oxidation current intensity is increase. Measurments of glutathione at SPCE-MIPpy provided better detection limit $(7.6626 \mu \mathrm{M})$ and quantitation limit $(25.4092 \mu \mathrm{M})$ compare to SPCE. The presence of glucose in the glutathione solution did not interfere the measurements of glutathione at SPCE-MIPpy. In conclusion, analytical performance of SPCE-MIPpy in GSH measurement was better than SPCE. 


\section{PENDAHULUAN}

Screen printed carbon electrode (SPCE) merupakan elektrode yang menggabungkan elektrode kerja berupa karbon, elektrode pembanding, dan elektrode pendukung dalam satu desain yang ringkas dan mudah digunakan. Dalam beberapa tahun terakhir SPCE semakin banyak digunakan dalam sensor elektrokimia. SPCE memiliki beberapa kelebihan seperti kemudahan dibawa dan digunakan, analisis cepat, efisiensi tinggi, biaya rendah, dan ukuran sampel yang kecil sehingga sangat prospektif untuk pengembangan sensor (Metters et al. 2011). Namun demikian karena electrode berbasis karbon seperti SPCE tidak selektif, maka diperlukan modifikasi untuk meningkatkan selektivitas elektrode terhadap analit target (Rana et al. 2016).

Selektivitas SPCE terhadap analit tertentu dapat ditingkatkan dengan menggunakan Molecularly imprinted polymer atau polimer tercetak molekul (MIP). MIP memiliki tapak molekul cetakan (biasanya molekul analit) sehingga selektivitas terhadap molekul analit meningkat. MIP yang banyak digunakan untuk deteksi elektrokimia ialah MIP polipirola (MIPpy). Polipirola banyak digunakan karena bersifat konduktif, mudah larut dalam air, dan mudah disintesis secara elektrokimia (Suratman et al. 2004; Wei et al. 2015). Pada penelitian ini MIP disiapkan dengan teknik elektropolimerisasi.

Penelitian ini bertujuan membuat SPCE termodifikasi MIPpy (SPCE-MIPpy) dan mengaplikasikannya untuk deteksi glutation (GSH). Glutation (Gambar 1) adalah molekul biologis penting berukuran kecil mengandung gugus tiol. Senyawa GSH memiliki peran penting dalam berbagai proses biologi termasuk perlindungan sel terhadap berbagai tekanan oksidatif, metabolisme xenobiotik, transduksi sinyal intra-seluler, dan regulasi gen. Selain itu glutation juga dapat berperan sebagai senyawa marker stress oxidative atau senyawa yang dapat digunakan sebagai indikator terjadinya stres oksidatif di dalam tubuh (Zhang et al. 2016).<smiles>NC(CCC(=O)NC(CS)C(=O)NCC(=O)O)C(=O)O</smiles>

Gambar 1. Struktur kimia GSH 


\section{METODE}

\section{Alat dan Bahan}

Alat-alat yang digunakan dalam penelitian meliputi alat gelas, potensiostat (EDAQ EA 163, Australia), neraca analitik (Sartorius), Screen Printed Carbon Electrode (Dropsens DRP 110, Spanyol) mikroskop elektron pemayaran (SEM) (Zeiss EVO MA 10, Jerman), serta perangkat lunak Echem v 2.1.0 dan Origin Pro 7.0. Bahan-bahan yang digunakan dalam penelitian meliputi Glutation tereduksi (GSH) (Sigma Aldrich, Amerika Serikat), pirola (Sigma Aldrich, Amerika Serikat), $\mathrm{NaClO}_{4}, \mathrm{NaBr}$, dan D-glukosa (Merck, Jerman), air deionisasi, dan akuades.

\section{Prosedur}

Penelitian ini terdiri atas 2 tahap utama, yaitu modifikasi SPCE dengan polipirola tercetak molekul GSH (SPCE-MIPpy) dan evaluasi kinerja SPCE dan SPCE-MIPpy. SPCE dimodifikasi menggunakan MIP polipirola melalui proses elektrodeposisi. SPCE-MIPpy dicirikan menggunakan SEM. SPCE-MIPpy dievaluasi kinerjanya menggunakan parameter linearitas, ketelitian, limit deteksi, limit kuantitasi, stabilitas, dan keterulangan serta dibandingkan dengan SPCE tanpa dimodifikasi. Pengukuran Voltammetri dilakukan menggunakan potensiostat EDAQ pada elektrode SPCE yang terdiri atas elektrode kerja (karbon), elektrode pembanding $(\mathrm{Ag} / \mathrm{AgCl})$, dan elektrode tambahan (karbon).

\section{Modifikasi SPCE Menggunakan MIP polipirola (MIPpy)}

MIP polipirola dibuat melalui deposisi siklik menggunakan potensiostat. SPCE dihubungkan dengan potensiotat menggunakan konektor. Larutan $\mathrm{H}_{2} \mathrm{SO}_{4} \quad 0.2 \mathrm{M}$ diteteskan pada permukan SPCE lalu dilakukan pemayaran dengan mode voltammetri siklik sebanyak 10 kali siklik pada jendela potensial $0-1.5 \mathrm{~V}$ dengan kecepatan payar $100 \mathrm{mV} / \mathrm{s}$ Permukaan SPCE dibilas dengan menggunakan air deionisasi. Selanjutnya larutan yang terdiri dari glutation $4 \mathrm{mM}$ dan monomer pirola $0.01 \mathrm{M}$ dalam $\mathrm{NaClO}_{4}$ diteteskan pada permukaan SPCE lalu dilakukan deposisi secara voltammetri siklik pada jendela potensial $-0.55 \mathrm{~V}-1.4 \mathrm{~V}$ dengan kecepatan payar $100 \mathrm{mV} / \mathrm{s}$. Kemudian pembentukan template dilakukan dengan meneteskan air deionisasi pada permukaan SPCE lalu dilakukan voltametri siklik pada jendela potensial $-0.6 \mathrm{~V}-1.0 \mathrm{~V}$ dengan kecepatan 
payar $100 \mathrm{mV} / \mathrm{s}$. SPCE termodifikasi polipirola tanpa molekul pencetak (SPCE-py) disiapkan dengan langkah yang sama dengan pembuatan SPCE-MIPpy tetapi tanpa penambahan GSH.

\section{Pencirian SPCE, SPCE-MIPpy, dan SPCE-py menggunakan SEM}

Morfologi permukaan SPCE, SPCE-py, dan SPCE-MIPpy dianalisis menggunakan SEM (Zeiss EVO MA 10) dengan potensial pemercepat $16 \mathrm{kV}$.

\section{Pengukuran GSH}

Glutation dilarutkan dalam air deionisasi kemudian dilakukan pengenceran dengan elektrolit (campuran $\mathrm{NaClO}_{4} 0.2 \mathrm{M}$ dan $\mathrm{NaBr} 1 \mathrm{mM}$ ). Dilakukan pengukuran voltammetry siklik pada jendela potensial tertentu dan dilakukan variasi kecepatan payar pengukuran pada selang 50 sampai $250 \mathrm{mV} / \mathrm{s}$

\section{Evaluasi Kinerja SPCE dan SPCE-MIPpy pada Pengukuran GSH}

Glutation dalam $\mathrm{NaClO}_{4}$ dengan penambahan $\mathrm{NaBr}$ dibuat variasi konsentrasi yaitu 1, 5, 10, 50, $100 \mu$ M. Larutan masing-masing diukur dengan voltammetri siklik untuk linearitas. Pengukuran juga dilakukan untuk mengevaluasi parameter ketelitian, limit deteksi, dan limit kuantitasi.

\section{Prosedur Analisis Data}

Arus dan potensial dari analit yang dibaca oleh potensiostat ditampilkan menggunakan aplikasi Echem dan diolah lebih lanjut menggunakan aplikasi Origin 7. Hasil olahan data berupa voltammogram

\section{HASIL DAN PEMBAHASAN}

\section{SPCE Termodifikasi Molecularly Imprinted Polymer Polipirola (SPCE-MIPpy)}

Polipirola disintesis melalui metode elektropolimerisasi. Metode elektropolimerisasi memiliki kelebihan antara lain dapat melapisi permukaan elektrode yang kecil dan tidak merata serta ketebalan lapisan dapat diatur (Panasyuk et al. 1998). Polipirola merupakan polimer konduktif karena memiliki kemampuan menghantarkan arus listrik. Kemampuan ini disebabkan adanya ikatan rangkap yang terkonjugasi. Polipirola dapat disintesis secara elektrokimia pada permukaan SPCE 
melalui elektropolimerisasi (Koirala et al. 2015). Dengan adanya pelarut dan elektrolit pendukung pirola akan teroksidasi pada permukaan elektrode kerja sehingga pelarut dan elektrolit pendukung yang digunakan dalam proses ini harus stabil (tidak mengalami reaksi redoks) pada potensial oksidasi pirola. Hasil oksidasi awal pirola membentuk radikal kation dan bereaksi dengan pirola lain dalam larutan membentuk oligomer dan selanjutnya terbentuk polimer. Anion yang berasal dari elektrolit pendukung berinteraksi secara elektrostatik dengan kation dalam polipirola sehingga muatan listrik dari membran yang terbentuk menjadi netral pada akhir reaksi (Suratman et al. 2004). Mekanisme elektropolimerisasi pirola dalam beberapa elektrolit pendukung ditunjukkan dalam mekanisme Reynold (Gambar 2).

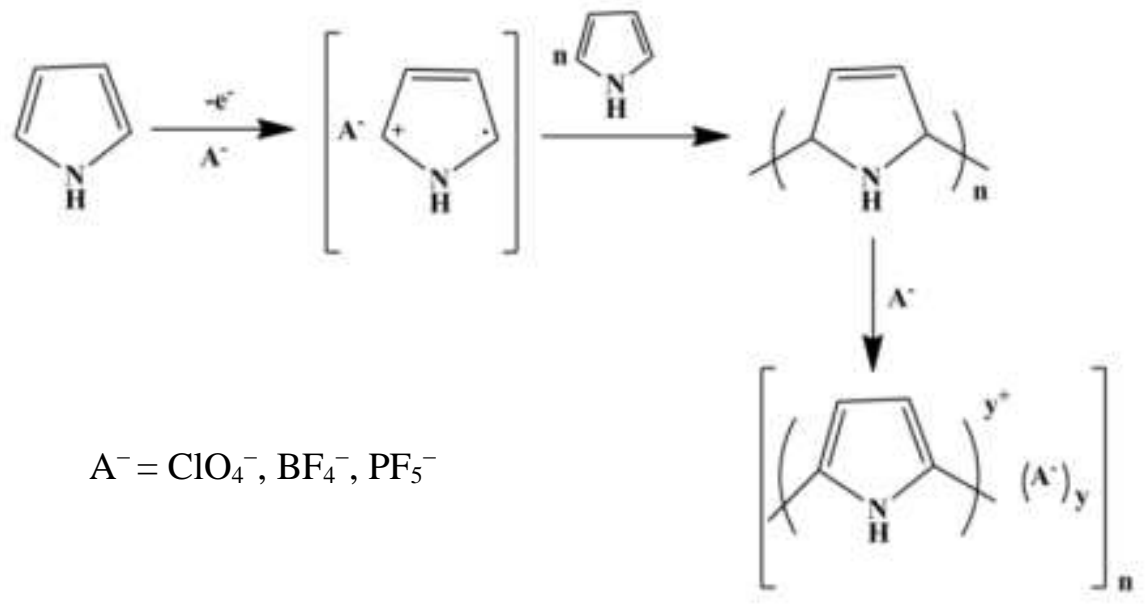

Gambar 2. Reaksi polimerisasi pirola membentuk polipirola berdasarkan mekanisme Reynold.

Pada akhir proses polimerisasi, GSH akan berada pada matriks polimer polipirola yang terbentuk. GSH yang berada di antara polimer tersebut selanjutnya diekstraksi menggunakan pelarut porogenik sehingga meninggalkan sebuah template yang mempunyai ukuran yang sama dengan GSH. Diharapkan hanya analit yang dapat mencapai permukaan elektrode dan menghasilkan respon arus puncak oksidasi. Terperangkapnya GSH dalam matriks polipirola disebabkan adanya ikatan hidrogen antara gugus $\mathrm{N}-\mathrm{H}$ pada pirola dengan gugus $\mathrm{O}-\mathrm{H}$ dan $\mathrm{N}-\mathrm{H}$ pada GSH. Dengan terbentuknya MIPpy diharapkan dapat meningkatkan selektivitas dan sensitivitas pada pengukuran GSH. 


\section{Morfologi SPCE, SPCE-MIPpy, dan SPCE-py}

Morfologi permukaan SPCE, SPCE-MIPpy, dan SPCE-py diamati menggunakan SEM. Permukaan SPCE terlihat kasar yang menunjukkan keberadaan karbon dalam permukaan elektrode kerja (Gambar 3A). Permukaan SPCE-MIPpy terlihat lebih halus, mengindikasikan telah terbentuknya lapisan tipis MIP polirola pada permukaan karbon dan selain itu terlihat bentuk menyerupai bulatan kecil yang mengindikasikan keberadaan agregasi polipirola di permukaan elektrode (Gambar 3B). Permukaan PCE-py terlihat lebih rapat dan kompak dibandingkan dengan SPCE MIP py (Gambar 3C). Pori cetakan molekul glutation pada permukaan polipirola tercetak glutation yang terbentuk tidak dapat teramati dengan jelas pada permukaan elektrode kerja. Hal ini disebabkan ukuran molekul atau template seharusnya berkisar 5-30 nm (Koirala et al. 2015) sedangkan yang teramati pada SEM hanya mencapai $1 \mu \mathrm{M}$ dengan perbesaran 10000 kali.

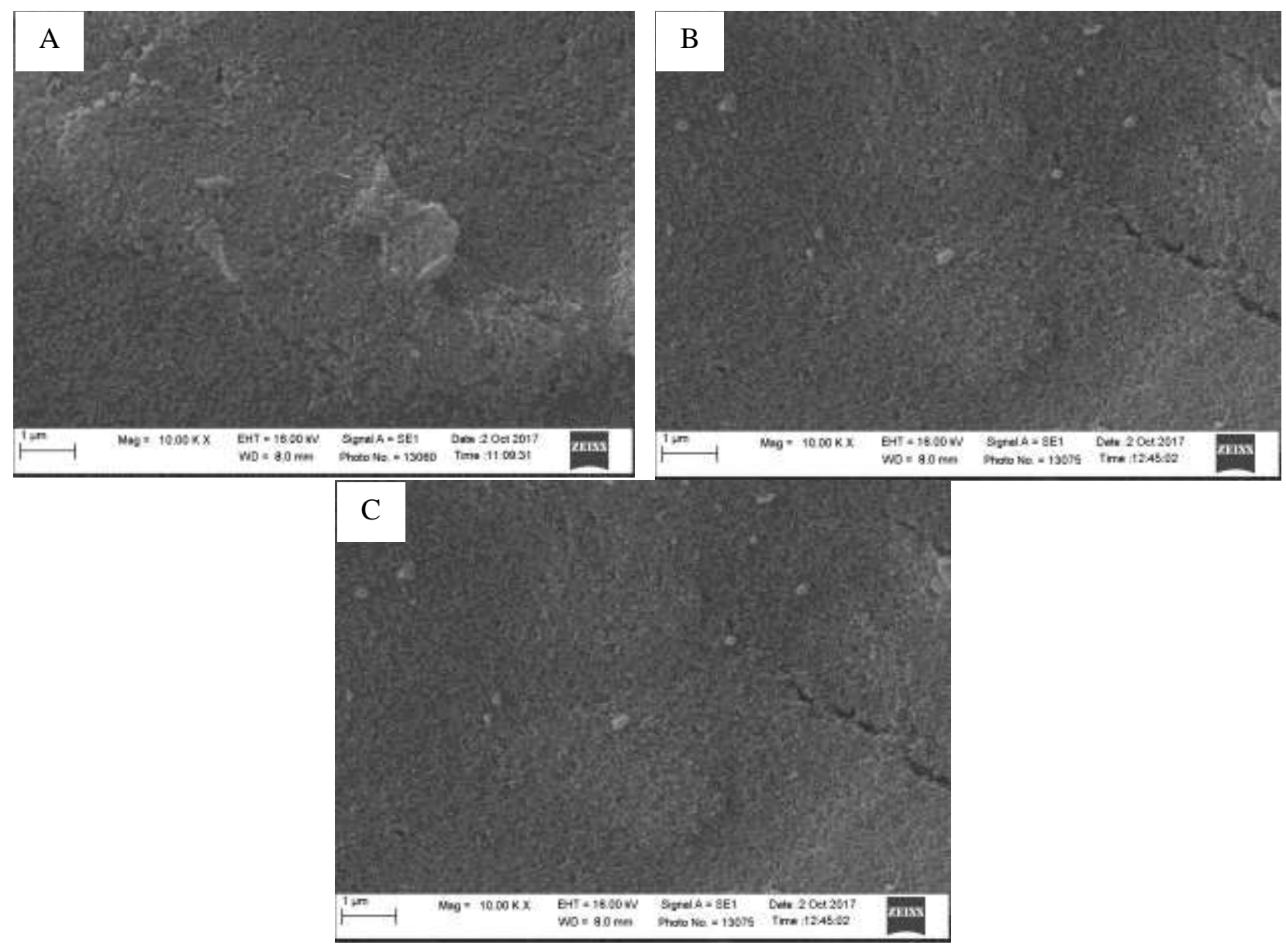

Gambar 3. Morfologi permukaan SPCE 10000 kali perbesaran (A), SPCE-MIPpy 10000 kali perbesaran (B) dan SPCE-Py 10000 kali perbesaran (C). 


\section{Respon Elektrokimia Glutation Tereduksi (GSH) Secara Tidak Langsung dengan Mediator Bromin}

Pengukuran GSH dilakukan secara tidak langsung dengan menggunakan tambahan senyawa halida yang mengandung bromida. Berdasarkan penelitian Valero-Ruiz et al. 2016 terjadi proses oksidasi bromida pada elektrode karbon lalu dilanjutkan dengan proses oksidasi GSH melalui mediator bromin. Reaksi oksidasi GSH dengan mediasi bromin menghasilkan senyawa sulfonat dan bromida. Berdasarkan reaksi ini puncak oksidasi yang terbaca merupakan puncak oksidasi bromida menghasilkan bromin. Namun puncak oksidasi ini memiliki hubungan yang linear dengan peningkatan konsentrasi GSH. Proses redoks yang terjadi menghasilkan arus puncak oksidasi sesuai dengan oksidasi dari satu elektron ion bromida yang diberikan (Persamaan 1 dan 2).

$$
\begin{aligned}
& \mathrm{Br}^{-} \rightleftharpoons \frac{1}{2} \mathrm{Br}_{2}+\mathrm{e}^{-} \\
& \mathrm{GSH}+3 \mathrm{Br}_{2}+3 \mathrm{H}_{2} \mathrm{O} \rightarrow \mathrm{GSO}_{3} \mathrm{H}+6 \mathrm{HBr}
\end{aligned}
$$

A

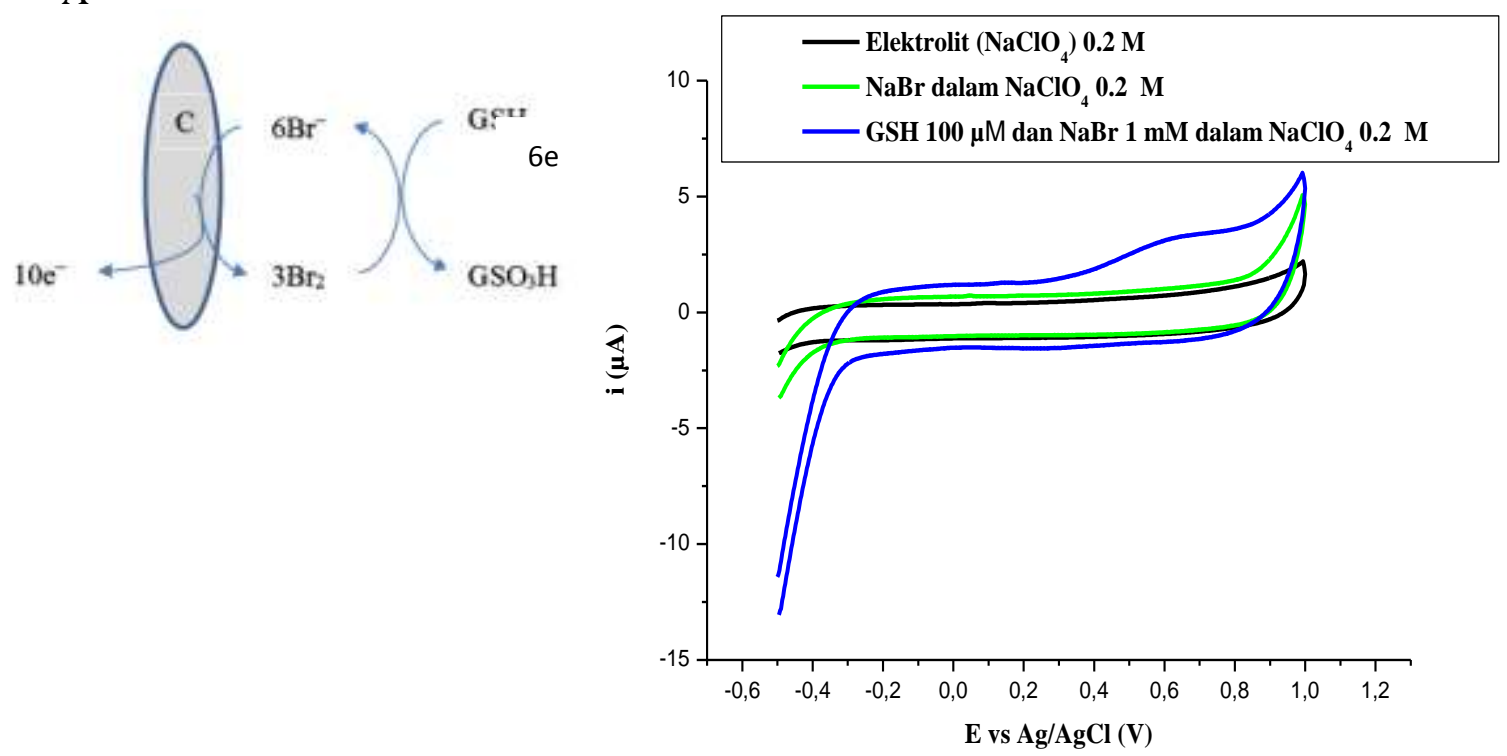

A

B

Gambar 4. Mekanisme elektrokatalitik untuk reaksi oksidasi glutation (GSH) secara elektrokimia pada elektroda karbon (A), Voltammogram siklik GSH $100 \mu \mathrm{M}$ dan $\mathrm{NaBr} 1 \mathrm{mM}$ dalam $\mathrm{NaClO}_{4} 0.2 \mathrm{M}$ diukur dengan SPCE pada kecepatan payar $100 \mathrm{mV} / \mathrm{s}$ (B) 
Naiknya konsentrasi GSH berdampak pada peningkatan arus puncak oksidasi dari bromida, mekanisme proses elektrokatalitik dari bromida diilustrasikan pada Gambar 4A. Bromin yang dihasilkan dari proses oksidasi bromida sebagian akan bereaksi dengan GSH membentuk sulfonat dan bromida. Bromida yang dihasilkan dari proses ini selanjutnya akan dioksidasi ulang sehingga mengakibatkan terjadinya pergeseran kesetimbangan kimia pada proses oksidasi bromida ke arah produk yang akhirnya memberikan efek pada peningkatan arus puncak oksidasi. Oleh karena itu mekanisme proses elektrokatalitik pada bromida ini sensitif terhadap konsentrasi dari GSH.

\section{Kondisi Pengukuran Glutation}

\section{Elektrolit Pendukung}

Larutan Elektrolit pendukung merupakan salah satu faktor yang perlu diperhatikan saat melakukan pengukuran secara voltammetri. Elektrolit berfungsi untuk mengurangi gaya tarik menarik elektrostatik antara muatan elektrode dengan muatan ion-ion analit dan mempertahankan kekuatan ion (Skoog et al. 2007). Elektrolit juga berperan sebagai media transfer elektron sehingga elektron bergerak ke permukaan elektrode dan terbaca sebagai arus (Wang 2000). Pada penelitian ini $\mathrm{NaClO}_{4}$ digunakan sebagai elektrolit karena tidak memberikan arus latar belakang yang berpengaruh terhadap pengukuran GSH. Selain itu penggunaan $\mathrm{NaClO}_{4}$ sebagai elektrolit juga bertujuan untuk memudahkan proses oksidasi dari bromida menjadi bromin yang akhirnya bereaksi dengan GSH membentuk sulfonat (Valero-Ruiz et al. 2016). Gambar 4B menunjukkan voltammogram siklik dari glutation tereduksi (GSH) $100 \mu \mathrm{M}$ dalam $\mathrm{NaClO}_{4} 0.2 \mathrm{M}$ yang mengandung $\mathrm{NaBr} 1 \mathrm{mM}$. Puncak oksidasi dari bromida $(0.63 \mathrm{~V}$ vs $\mathrm{Ag} / \mathrm{AgCl}$ ) tidak terganggu dengan keberadaan arus latar belakang dari elektrolit $\mathrm{NaClO}_{4} 0.2 \mathrm{M}$.

\section{Kecepatan Payar}

Evaluasi kecepatan payar dilakukan untuk mengetahui hubungan antara kecepatan payar dengan intensitas arus. Kecepatan payar berpengaruh terhadap intensitas puncak oksidasi bromida yang dihasilkan. Berdasarkan evaluasi yang dilakukan diperoleh logaritmik kecepatan payar berbanding lurus dengan dengan logaritmik intensitas arus puncak oksidasi bromida (Gambar 5) mengindikasikan puncak oksidasi dikontrol difusi dan adsorpsi. Pengukuran GSH 
selanjutnya dilakukan pada kecepatan payar $100 \mathrm{mV} / \mathrm{s}$. Pada kecepatan payar yang lebih tinggi atau rendah arus puncak oksidasi bromida tidak muncul secara konsisten disebabkan oksidasi bromida tidak terjadi secara sempurna. Pada kecepatan rendah transfer elektron antara elektrode dengan analit terjadi dengan lambat, sementara pada pada kecepatan tinggi ketebalan lapisan difusi akan meningkat.

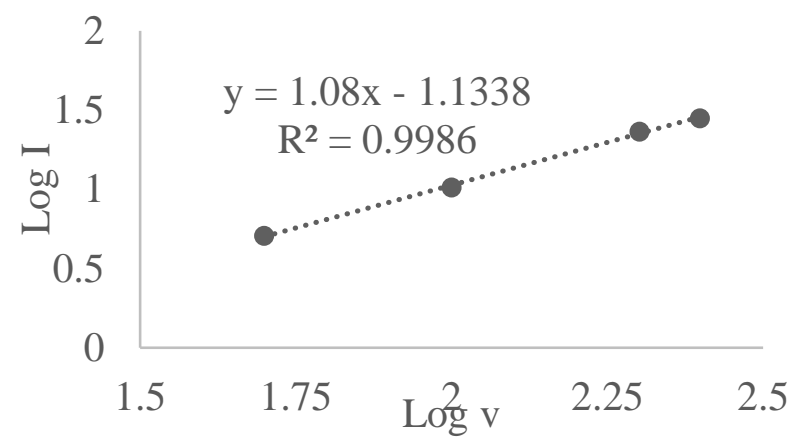

Gambar 5. Hubungan antara log v dengan log I

\section{Kinerja SPCE, SPCE-MIPpy, SPCE-py pada Pengukuran Glutation}

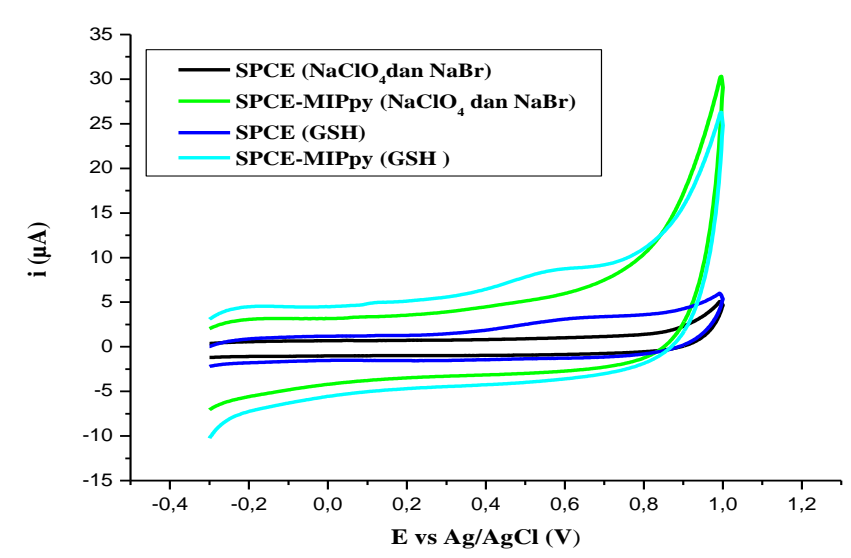

A

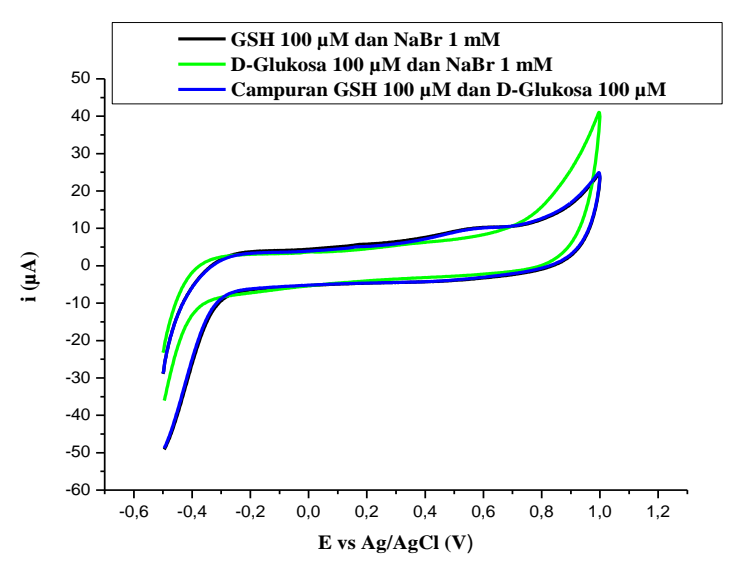

B

Gambar 6. Voltammogram siklik GSH $100 \mu \mathrm{M}$ dalam $\mathrm{NaBr} 1 \mathrm{mM}-\mathrm{NaClO}_{4}$ diukur mengg unakan SPCE dan SPCE MIPpy (A), Voltammogram siklik GSH $100 \mu \mathrm{M}$, D-glukosa $100 \mu \mathrm{M}$, dan campurannya diukur menggunakan SPCE-MIPpy

Setelah dilakukan modifikasi MIPpy pada permukaan elektrode, terjadi kenaikan intensitas arus puncak oksidasi bromida yang terbaca sebesar 2.9 kali dibandingkan dengan 
pengukuran menggunakan SPCE (Gambar 6A). Hal ini disebabkan karena polipirola memiliki sifat konduktivitas listrik yang baik sehingga proses transfer elektron pada permukaan SPCEMIPpy lebih mudah terjadi. Dalam penelitian ini analit hanya dapat diukur menggunakan SPCE dan SPCE-MIPpy sedangkan SPCE-py tidak dapat digunakan untuk mendeteksi keberadaan campuran GSH dan bromida. Hal ini dikarenakan arus puncak oksidasi bromida tidak terlihat dalam voltammogram yang dihasilkan oleh SPCE-py.

\section{Selektivitas SPCE-MIPpy pada Pengukuran GSH}

Selektivitas adalah kemampuan metode untuk mengukur dengan tepat dan spesifik suatu analit tertentu dengan keberadaan komponen lain yang terdapat dalam sampel. Selektivitas dievaluasi untuk memastikan bahwa hanya analit yang yang dapat dideteksi tanpa adanya gangguan dari senyawa lain. Selektivitas SPCE-MIPpy pada pengukuran GSH dievaluasi menggunakan D-glukosa sebagai pengganggu. Deteksi glutation secara tidak langsung dengan tambahan bromida menggunakan SPCE-MIPpy diharapkan dapat diaplikasikan dalam sampel darah. Pemilihan glukosa sebagai interference dikarenakan keberadaan senyawa tersebut dalam darah sering terdeteksi menghasilkan puncak oksidasi bersama glutation.

Hasil yang diperoleh menunjukkan bahwa SPCE-MIPpy dapat mendeteksi glutation tanpa diganggu puncak oksidasi glukosa (Gambar 6B). Puncak oksidasi dari glukosa tidak dapat terdeteksi karena pengukuran glukosa memerlukan rentang potensial yang lebih lebar dikarenakan aktivitas oksidasinya kecil sehingga memerlukan senyawa lain sebagai katalisator untuk pengukuran glukosa. Selain itu tidak dihasilkannya puncak arus dari glukosa menunjukkan keberadaan bromin dalam larutan hanya dapat bereaksi dengan glutation. Arus puncak yang muncul pada voltammogram merupakan puncak oksidasi dari bromida dan puncak tersebut akan meningkat intensitasnya seiring dengan meningkatnya konsentrasi GSH (Valero-Ruiz et al. 2016).

\section{Linearitas}

Linearitas pengukuran GSH pada SPCE dan SPCE-MIPpy dievaluasi dengan mengukur GSH pada rentang konsentrasi $1-100 \mu \mathrm{M}$ pada masing-masing elektrode. Berdasarkan hasil yang diperoleh, meningkatnya konsentrasi GSH menyebabkan intensitas arus puncak oksidasi 
bromida yang dihasilkan juga semakin meningkat. Hal ini disebabkan bromin yang dihasilkan dari proses oksidasi bromida akan digunakan untuk reaksi reduksi bersama dengan GSH yang akhirnya menghasilkan produk berupa senyawa sulfonat dan pembentukan kembali bromida. Persamaan regresi linear yang diperoleh untuk pengukuran GSH menggunakan SPCE dan SPCEMIPpy berturut-turut adalah $i_{\mathrm{pa}}(\mu \mathrm{A})=24019 \mathrm{x}+1.28\left(R^{2}=0.9844\right)$ dan $i_{\mathrm{pa}}(\mu \mathrm{A})=19981.83+$ $6.73\left(R^{2}=0.9870\right)$. Nilai koefisien determinasi dari kurva hubungan konsentrasi GSH dengan arus puncak oksidasi pada pengukuran dengan SPCE-MIPpy lebih baik dibandingkan pengukuran pada SPCE (Gambar 7).

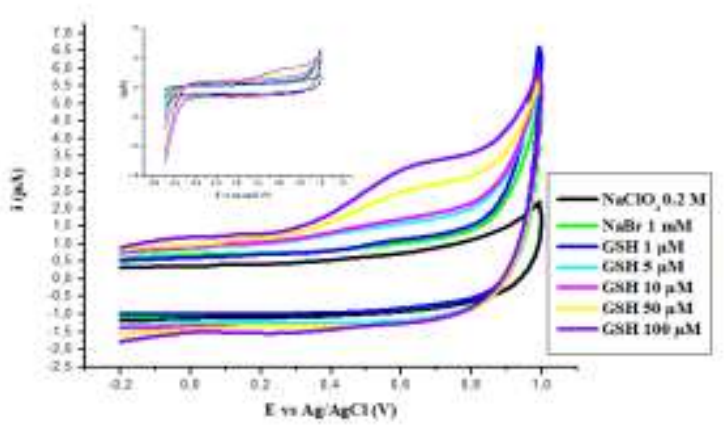

A

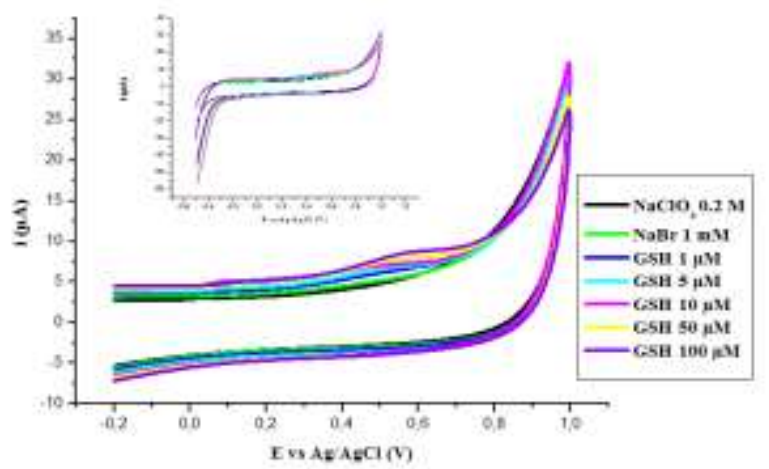

B

Gambar 7. Voltamogram siklik GSH berbagai konsentrasi dalam $\mathrm{NaBr} 1 \mathrm{mM}-\mathrm{NaClO}_{4} 0.2 \mathrm{M}$ mM pada SPCE (A) dan SPCE-MIPpy (B). Inset: voltammogram siklik GSH $100 \mu \mathrm{M}$

\section{Limit Deteksi dan Limit Kuantitasi}

Limit deteksi (LD) pengukuran GSH pada SPCE-MIPpy sebesar 7.6 $\mu \mathrm{M}$. Nilai LD ini 2.1 kali lebih rendah dibandingkan SPCE. Hal ini menunjukkan sensitivitas SPCE-MIPpy untuk pengukuran glutation lebih tinggi dibandingkan SPCE. Limit Kuantitasi (LK) pengukuran GSH pada SPCE-MIPpy sebesar $25.4 \mu \mathrm{M}$, yaitu 2.1 kali lebih rendah dibandingkan SPCE, artinya SPCE-MIPpy dapat digunakan dengan cukup baik untuk pengukuran GSH pada tingkat konsentrasi yang rendah.

\section{Presisi Pengukuran GSH dengan SPCE dan SPCE-MIPpy}

Presisi dinyatakan dalam nilai persen simpangan baku relatif (\%SBR). Semakin kecil nilai \%SBR semakin teliti metode atau teknik yang digunakan. Pada orde konsentrasi yang digunakan dalam pengukuran, presisi dicapai apabila $\%$ SBR $\leq 5 \%$. Nilai $\%$ SBR pengukuran 
GSH pada SPCE dan SPCE-MIPpy berturut-turut sebesar 3.34\% dan 0.96\% (data lengkap tidak ditampilkan). Nilai \%SBR tersebut mengindikasikan pengukuran GSH pada kedua jenis elektrode presisi.

\section{Stabilitas SPCE dan SPCE-MIPpy}

Stabilitas dievaluasi dengan melakukan pemayaran berkali-kali hingga mencapai nilai \%SBR yang masih dalam batas toleransi yaitu kurang dari 5\% (ICH 2005). Stabilitas arus oksidasi yang dihasilkan SPCE-MIPpy lebih baik dibandingkan SPCE. Respon arus puncak oksidasi yang dihasilkan oleh SPCE-MIPpy stabil sampai 17 kali siklisasi dengan nilai \%SBR 3.6629\% dan SPCE stabil hingga 9 kali siklisasi dengan nilai \%SBR 3.3904\%. Sedangkan jika dilihat dari potensial arus puncak oksidasinya nilai \%SBR pengukuran GSH pada SPCE-MIPpy (3.9029 \%) lebih baik dibandingkan pada SPCE (8.6591 \%). Secara keseluruhan SPCE-MIPpy memiliki sensitivitas dan stabilitas yang lebih tinggi dibandingkan dengan SPCE.

Tabel 1. Ringkasan kinerja analitik SPCE dan SPCE-MIPpy pada pengukuran GSH

\begin{tabular}{lllc}
\hline Parameter & SPCE & $\begin{array}{l}\text { SPCE- } \\
\text { MIPpy }\end{array}$ & $\begin{array}{l}\text { *SPPtE } \\
\text { (Valero-Ruiz } \\
\text { et al. 2016) }\end{array}$ \\
\hline Potensial oksidasi $(\mathrm{V})$ & & 0.63 & 0.97 \\
Selang Linearitas $(\mu \mathrm{M})$ & 0.63 & $1-100$ & $19.9-210.7$ \\
Kemiringan $(\mu \mathrm{A} / \mathrm{M})$ & $1-100$ & 19981.83 & - \\
Intersep $(\mu \mathrm{A})$ & 24019 & 6.7283 & - \\
Koefisisen Determinasi $\left(R^{2}\right)$ & 1.281 & 0.987 & 21.28 \\
LD $(\mu \mathrm{M})$ & 0.9844 & 7.6226 & \\
LK $(\mu \mathrm{M})$ & 15.8203 & 25.4092 & \\
Stabilitas arus puncak oksidasi $(\%$ SBR) & 3.3904 & 3.6629 & \\
Stabilitas potensial oksidasi $(\%$ SBR) & 8.6591 & 3.9029 & \\
\hline
\end{tabular}

*SPPtE : Screen Printed Platinum Electrode 
Perbandingan kinerja analitik pengukuran GSH pada penelitian ini dievaluasi dengan merujuk pada penelitian yang dilakukan oleh Valero-Ruiz et al. 2016. Pada penelitian ini digunakan Screen Printed Electrode sebagai elektrode kerja dan $\mathrm{Ag} / \mathrm{AgCl}$ sebagai elektrode pembanding. Sementara itu Valero-Ruiz et al. 2016 menggunakan SPE berbasis platina sebagai elektrode kerja dan kalomel jenuh sebagai elektrode pembanding.

\section{KESIMPULAN}

SPCE berhasil dimodifikasi dengan Molecularly Imprinted Polymer polipirola (SPCEMIPpy). GSH dapat dideteksi dengan SPCE dan SPCE-MIPpy secara tidak langsung dengan penambahan $\mathrm{NaBr}$ pada larutan GSH dan pengukuran menggunakan metode voltammetri siklik. Kinerja analitik pengukuran GSH pada SPCE-MIPpy lebih baik dibandingkan SPCE. Keberadaan interference glukosa tidak mengganggu pengukuran glutation pada SPCE-MIPpy.

\section{UCAPAN TERIMA KASIH}

Ucapan terima kasih disampaikan kepada Direktorat Riset dan Pengabdian Masyarakat Direktorat Jenderal Penguatan Riset dan Pengembangan Kementerian Riset, Teknologi dan Pendidikan Tinggi atas pendanaan riset melalui program Penelitian Fundamental Sesuai dengan Surat Perjanjian Penugasan Pelaksanaan Program Penelitian Nomor: 011/SP2H/LT/DRPM/VIII/2017.

\section{DAFTAR PUSTAKA}

[ICH] International Conference on Harmonisation, 2005, Validation of Analytical Procedures.

Koirala, K., Sevilla, F.B., Santos, J.H., 2015, Biomimetic potentiometric sensor for chlorgenic acid based electrosynthesized polypyrrole. Sensor and Actuators B, 222, 391-396. doi.org/10.1016/j.snb.2015.08.084

Metters, P., Kadara, R.O., Banks, C.E., 2011, New directions in screen printed electroanalytical sensors: an overview of recent developments. Analyst, 136, 1067-1076.

Panasyuk, T., Dall'Orto, V.C., Marrazza, G., El'skaya, A., Piletsky, S., Rezzano, I., Mascini, M., 1998, Molecular Imprintes polymers prepared by electropolymerization of $\mathrm{Ni}$ (Protoporphyrin IX). Analytical Latters, 31(11), 1809-1824. 
Rana, S., Mittal, S.K., Singh, N., Singh, J., Banks, C.E., 2016, Schiff base modified Screen Printed Electrode for selective determination of Aluminium (III) at trace level. Sensors and Actuators B, 16, 1-37.

Skoog, D.A., Holler, F.J., Crouch, S.R., 2007, Principles of Instrumental Analysis sixth edition. Canada (CD): Thomson books/cole.

Suratman, A., Buchari, Noviandri, I., Gandasasmita, S., 2004, Study of electropolimerization processes of polypyrrole by cyclic voltammetric technique. Indonesian Journal of Chemistry, 4(2), 117-124.

Valero-Ruiz, E., Sanchez, M.I.G., McAuley, C.B., Compton, R.G., 2016, Halogen mediated voltammetric oxidation of biological thiols and disulfides. Royal Society of Chemistry, 10.1039/c5an01955a.

Wang, J., 2000, Analytical Electrochemistry second edition. New York (US): Wiley-VCH.

Wei, H., He, C., Liu, J., Gu, H., Wang, Y., Yan, X., Guo, J., Ding, D., Shen, N.Z., Wang, X., et $a l$, 2015, Electropolymerized polypyrrole nanocomposites with cobalt oxide coated on carbon paper for electrochemical energy storage. Polymer Journal, 67, 192-199. doi.org/10.1016/j.polymer.2015.04.064

Zhang, H., Zhang, L., Ding, Y., Zhang, W., Zhang, X., Shen, Y., Yang, F., 2016, Determination of glutathione based on NiPd nanoparticles mediated with acetaminophen. Royal Society of Chemistry, 1, 1-6.10.1039/C6AY00171H. 